\title{
The Coparation between Exclusive Breastfeeding and Infant's Development at the Age of 6 Months in Rskia Pertiwi Makassar South Sulawesi Indonesia
}

\author{
Sundari $^{1}$, Andi masnilawati ${ }^{2}$, Daswati $^{3}$, Lina Fitriani ${ }^{4}$, Sitti Hadriyanti ${ }^{5}$, Sumiaty ${ }^{6}$, Nurlina Akbar ${ }^{7}$ \\ ${ }^{1}$ Lecturer of Department of Midwifery, School of Public Health, the Indonesian Muslim University \\ ${ }^{2}$ Lecturer of Department of Midwifery, School of Public Health, the Indonesian Muslim University, 3Lecturer \\ of Departemen of Midwifery, Muhammadiyah University, ${ }^{4}$ Lecturer of STIKES bina Generasi Polewali Mandar, \\ ${ }^{5}$ Lecturer of Department of Midwifery, School of Public Health, the Indonesian Muslim University, ${ }^{6}$ \\ Lecturer of the Ministry of Health's Department of Obstetrics Polytechnic of Southeast Sulawesi Palu, ${ }^{7}$ Lecturer \\ of Department of Midwifery, School of Public Health, the Indonesian Muslim University
}

\begin{abstract}
Background: The growth and development of children is influenced by nutritional factors, one of which is exclusive breastfeeding. It is known that until the age of 6 months of breastfeeding. (ASI) is an ideal food for babies both in terms of physical and psychological health.

Research Purpose: This research compare development of babies aged 6 months who were breastfed exclusion and not exclusively breastfed.

Research method: This study uses a case control design and conducted in 2017. The research subjects infants aged 6 months were exclusively breastfed and not breastfed exclusively in RSKIA Pertiwi Makassar. Development of infants assessed with the scale KPSP (Pre-Screening Questionnaire Development). exclusive breastfeeding effect on the development analyzed by $t$.

Conclusion: The results showed the development of exclusively breastfed infants given a significant $(\mathrm{p}$ $<0.05$ ), clinically obtained the value of OR 36,75 means that infants fed exclusively breastfed increased 36 , 75 times more suitable compared groups of infants who are not breastfed exclusively.
\end{abstract}

Keywords: Exclusive breastfeeding, Development, KPSP.

\section{Introduction}

The growth and development of children is influenced by nutritional factors, one of which is exclusive breastfeeding. It is known that until the age of 6 months of breastfeeding. (ASI) is an ideal food for babies both in terms of physical and psychological health. ${ }^{1}$ premisesn exclusive breastfeeding until the baby is 6 months old will ensure the achievement of the development of children's intelligence potential optimally. Mother's milk other than as a nutrient that is ideal, with the right composition, as well as tailored to the needs of the baby, breast milk also contains nutrients specialty such as taurine, lactose, AA, DHA, omega 3, omega 6 , choline, and tryptophan needed baby's brain to grow sinapto- optimal to assist in the genesis and the process of myelination. The more synapses between nerve cells more complex the ability to receive, process, store and respond stimuli received by the nerve cells. In general the number of synapses increases rapidly between the ages of 3-4 months, then going relationship with visual information processing center until the age of 6 months ${ }^{2-4}$.

The Kemenkes ${ }^{5}$ recommends exclusive breastfeeding for the first 6 months of life and continued until the age of 2 years. Breast milk is the best food for babies because it contains all the nutrients a baby needs in appropriate amounts and immunologic substances that protect the baby from infection. Based on the accumulated 
evidence of the protective effect of breast milk protects against infectious diseases including for example, digestion and breathing. Moreover, the lingering effects where breastfeeding potential to prevent at some of the results that have been studied for preventing obesity in children, improve cognitive function, prevent dental caries, gastric disorders and respiratory disorders. This is due to the presence of antibodies contained in breast milk colostrum. Feeding can regulate energy intake associated with the internal response in recognizing the feeling of satiety ${ }^{5-7}$.

The development is increasing the body's structure and function is more complex in coarse motion capability, smooth motion, speech and language as well as socialization and independence. The development is the result of the maturity of the central nervous system interaction with the affected organ, such as the development of the neuromuscular system, speech, emotion and socialization. Impaired development could result in the emergence of several possibilities, including speech delays caused Child Global Development Delay (general psychomotor developmental delay), abnormalities of the sensory nerves to the hearing, Down Syndrome, and autism ${ }^{8}$.

Screening / examination using KKSP child development (pre-screening questionnaire development) to know normal child development or not. KKSP used as deemed relevant in analyzing the development of the appropriate stages of the child's age $\mathrm{e}^{9,10 .}$

With regard to the importance of the development of exclusive breast-fed infants, the authors wanted to do research on cognitive function comparison infants aged 6 months who have received and are not exclusively breastfed and selected research sites in Makassar due to declining rates of exclusive breastfeeding in infants in Makassar.

\section{Materials and Methods}

\section{Research Location}

Research was conducted The Pertiwi RSKDIA Makassar,

\section{Research design}

This research is a kind of analytical research using case control design. Subjects were all infants aged 6 months in RSKDIA Pertiwi Makasar exclusively breastfed and who are not exclusively breastfed.

\section{Population}

Population is the research object or object under study Notoadmodjo ${ }^{11}$. As for the population in this study is a 6-month-old baby, either given or not given exclusive breastfeeding in Makassar.

\section{samples}

Samples are partly taken from the whole object under study were considered representative of the entire population ${ }^{11}$. The samples in this study were part of the population of babies aged 6 months, either given or not given exclusive breastfeeding in Makassar. To determine the sample, in this study researchers used a purposive sampling technique

\section{Results}

\section{The univariate analysis}

Research has been conducted on 60 mothers who had infants aged 6 months. Data characteristics of the respondents in this study include the mother's age, education, occupation, age of the last child, knowledge, exclusive breastfeeding.

1. characteristics of respondents

Table 1 Characteristics of Respondents by age of mother

\begin{tabular}{|l|l|l|}
\hline Age & frequency & Percent (\%) \\
\hline$\leq 35$ years old & 29 & 48.33 \\
\hline$>35$ years & 31 & 51.67 \\
\hline Total & 60 & 100 \\
\hline
\end{tabular}

Source: Primary Data Year 2017

Table 1 shows that 60 respondents, obtained with age $\leq 35$ years as many as 29 respondents $(48.33 \%$ ), While respondents with age $>35$ years as many 31 respondents $(51.67 \%)$

\section{Breastfeeding}


Table 2 Characteristics of Respondents in Breastfeeding

\begin{tabular}{|l|l|l|}
\hline breastfeeding & F & \% \\
\hline Exclusive breastfeeding & 30 & 50 \\
\hline not Exclusive & 30 & 59 \\
\hline Total & 60 & 100 \\
\hline
\end{tabular}

Source: Primary Data Year 2017

Table 2 shows that 60 respondents, found respondents give Exclusive breastfeeding 30 (50\%), while those not exclusively breastfed were $30(50 \%)$ of respondents.

3. Baby's development

Table 3 Development of Infants

\begin{tabular}{|l|l|l|}
\hline infant development & F & \% \\
\hline Corresponding & 36 & 60 \\
\hline question & 23 & 38.33 \\
\hline digress & 1 & 1.67 \\
\hline Total & 60 & 100 \\
\hline
\end{tabular}

Table 3 shows that out of 60 babies, infant development according the growth obtained a total of $36(60 \%)$, development of infants doubt there are $23(38.33 \%)$, while the development of the baby deviation of $1(1.67 \%)$ infants.

4. Exclusive breastfeeding comparison with developments in Infants

Table 4: Development of Infants

\begin{tabular}{|c|c|c|c|c|c|c|c|c|c|c|}
\hline & \multicolumn{10}{|c|}{ infant development } \\
\hline & \multirow{2}{*}{\multicolumn{2}{|c|}{ Corresponding }} & \multirow{2}{*}{\multicolumn{2}{|c|}{ question }} & \multirow{2}{*}{\multicolumn{2}{|c|}{ digress }} & \multicolumn{2}{|c|}{ Corresponding } & \multicolumn{2}{|c|}{ digress } \\
\hline & & & & & & & $\mathbf{P}$ & OR & $\mathbf{P}$ & $\mathbf{R R}$ \\
\hline & $\mathrm{n}$ & $\%$ & $\mathrm{n}$ & $\%$ & $\mathrm{n}$ & $\%$ & CI $95 \%$ & & & \\
\hline \multicolumn{11}{|l|}{ care } \\
\hline exclusive & 28 & & 2 & & 0 & & $<0.001$ & 36.75 & - & - \\
\hline not Exclusive & 8 & & 21 & & 1 & & $6.29-35$ & & - & \\
\hline
\end{tabular}

Source: Primary Data Year 2017 
Table 4 showed that exclusive breastfeeding comparison to the development of infant outcome was significant $(\mathrm{P}<0.05)$. Clinically obtained OR 36.75 value means that infants given breast milk for exclusive development corresponding 36.75 times more than those who are not breastfeeding exclusively.

\section{Discussion}

Breastfeeding will make the baby feel sticky and safe. Sense have a baby in the first and second year of life. Breastfeeding infants will help the optimal development after the perinatal period. Accordingly, the results of this study stated that earned comparisons infant development given exclusive breastfeeding at $\mathrm{P}<0.05$ by babies who are not breastfed exclusively. Clinically obtained OR 36.75 value means that infants given breast milk for exclusive development corresponding 36.75 times more than the group of infants who were not given breast milk exclusively. This suitability is because breast milk has nutrients that are best and most complete comparison with other prelakteal foods including infant formula. Type breastfeeding given to infants 6 months of age can also affect the results. This is in line with research conducted by Any $\mathrm{S}$, et $a l^{12}$ that shows that children who are breastfed exclusively the majority (76.2\%) did not have the mental emotional problems, while children who do not consume exclusively breastfed tend to have mental emotional problems (64.3\%). Based on the research results Ida, et al ${ }^{13}$ on the status of breastfeeding in infants aged 0-6 months got that out of 76 respondents there were 42 respondents $(55.3 \%)$ exclusive breastfeeding to their babies and there are 34 respondents (44.7\%) did not exclusive breastfeeding to their babies. Babies who are exclusively breastfed will get all the advantages of breastfeeding and nutritional needs are met to the fullest and will experience optimal growth and development. Research Anes $\mathrm{MP}^{14}$ also showed significant between exclusive breastfeeding with no developmental differences in infants aged 6 to 12 months in Beji Depok subdistrict health center. The results showed that exclusively breast-fed babies are at risk 9.5 times progressing appropriate than experiencing developmental disorders when compared to babies who are not breastfed exclusively.

This can occur because milk contains vital substances needed by babies including protein, carbohydrate, and fat accumulated alveolar of breast. Here excess milk composition when compared to other formula: first, the protein in breast milk is more easily digested than protein available in infant formula. Protein in milk contains about $6 \%$ of calories. Additionally, Lactose is the main carbohydrate. Carbohydrates in Human milk contains about $42 \%$ of calories. Then, cholesterol as the most essential substances in the highest brain development contained in breast milk. Milk fat contains about $52 \%$ of calories. Breast milk also contains vitamins and minerals that are transferred from maternal plasma and lastly, Breast milk contains antibodies from the maternal system which can reduce the danger of infection of newborns ${ }^{15-17}$. Thus, exclusive breastfeeding can boost development in infants because of all the nutrients that the baby needs to achieve the developmental stage, can be met by breast milk. Other research also has the same result is the research conducted by Lidya. N.M and Rodiah ${ }^{13}$ in Karang Anyar health center which shows the significance of the development of exclusive breastfeeding in infants aged 3 to 6 months.

In addition, research conducted states that there is a positive relationship between the duration of exclusive breastfeeding within months with the motor component in children and in the overall index of development of children up to the age of 6 years $^{18}$. Another study conducted by Bodnarchuk and Jenifer ${ }^{19}$ in Canada also said that the long duration of breastfeeding can enhance cognitive abilities and motor development of infants; motor development (particularly the ability to crawl in infants) can trigger significant changes in the baby's cognitive ability. In another study conducted in Europe with a cohort design, the data found that children who were exclusively breastfed up to 3 full months, had an average rate of intelligence (IQ) 2, 1 point higher than the other children. While the children are breastfed up to 4-6 months had an average rate of intellect 2.6 points higher than that of other children. And the benefits for children who are breastfed longer ( $>6$ months) may increase the child's intellectual intelligence to 3.8 points higher than children who are not breastfed exclusively. Increased intelligence in infants, will have an impact on improving the development of gross motor, fine motor, language and social independence in infants 8 points higher than children who are not breastfed exclusively. Increased intelligence in infants, will have an impact on improving the development of gross motor, fine motor, 
language and social independence in infants 8 points higher than children who are not breastfed exclusively. Increased intelligence in infants, will have an impact on improving the development of gross motor, fine motor, language and social independence in infants

Other studies obtained different results with this study is the result of research conducted in sragen known to most of the growth of children 1-6 months are breastfed exclusively or non-exclusive breastfeeding in the normal category. Most child development given 1-6 months exclusive breastfeeding and exclusive breastfeeding is not normal. No difference between the growth of children breast-fed exclusively with not exclusive ASI. No difference between the child's development in breastfed exclusively with the nonexclusive breast-fed.

\section{Conclusions and Suggestions}

The results showed that there are $60 \%$ of infants who breastfed exclusively had been developed accordingly. While $38.33 \%$ Were not given exclusive breastfeeding progressing dubious and there $1.67 \%$ deviate baby development because it is not exclusively breast-fed. The study states that there is a significant relationship between exclusive breastfeeding with the development in infants. Infants given breast milk for exclusive development corresponding 36.75 times more than those who are not breastfeeding exclusively

Further studies on the things that relate to the development of children who are limitations to this study as a stimulus factor, systemic disease factors, and comparison of the frequency of breastfeeding and giving PASI. In addition, other researchers also need to use the data scale and measuring devices are better than the ones used in this study. The study design with the casecontrol approach also will show better results.

Ethical Clearance- Taken from ethical university committee

\section{Source of Funding- Self}

\section{Conflict of Interest - Nil}

\section{References}

1. Tanuwidjaya S. Konsep umum tumbuh dan kembang. Dalam: Narendra MB, Sularyo TS,
Soetjiningsih, Suyitno H, Gde Ranuh IGN, penyunting. Tumbuh kembang anak dan remaja. Sagung Seto. 2000; 1-12

2. Nelson CA . The neurobiological bases of early inter vention. Dalam Shonkoff JP, Meisels SJ, penyunting. Handbook of early childhood interventiont. Edisi ke-2. Cambridge: University Press,. 2000; h. 204-30.

3. Anwar Mallongi, Stang, Syamsuar, Hasnawati Amqam, Aminuddin Syam, Syahrul Basri, Muh. Saleh. Target Cancer Risks Due To The Exposure From Silica Among The Communities Living Surround Cement Tonasa Industry Pangkep, Indonesia. Interciencia Journal. 2019 44(11)

4. Wardana et al, IOP Conf. Ser.: Earth Environ. Sci. 2019; 235012101

5. Kemenkes Stimulasi, Deteksi dan Intervensi Dini Tumbuh Kembang Anak di Tingkat Pelayanan Kesehatan Dasar. Depkes Dirjen Pembina Kesehatan Masyarakat. 2015.

6. Kramer, M.S \& Kakuma, R. Optimal duration of exclusive breastfeeding. Cochrane Database Syst Rev; 2012; CD003517.

7. Sutomo dan Anggraini, D. Makanan Sehat Pendamping ASI. Penerbit Demedia Pustaka Jakarta. 2010

8. Horta B \& Victor C. Long-term effects of breastfeeding: A systematic review: Worl Hodnett E D, Gates S, Hofrney G and Sakala C. 2003. Continuous support for women during childbirth. The Cochrane Database of Systematic Reviews 2003, Issue 3. Health Organization. Geneva, Switzerland. 2013

9. Rusmil Kusnadi. Tumbuh Kembang Anak Ditingkat Pelayanan Kesehatan Dasar. Departemen Kesehatan RI. 2006.

10. Glick, M. Tumbuh Kembang Anak Usia Balita. Jakarta: EGC, 2010

11. Notoatmodjo S. Metodologi Penelitian kesehatan. Rineka Cipta. Jakarta. 2002

12. Any S, Maria M, Ani M. Pengaruh pemberian asi eksklusif dan non eksklusif terhadap mental emosional anak usia 3-4 tahun. Jurnal Gizi Indonesia (ISBN : 1858-4942), 2015; Vol. 4, No. 1: 16-21

13. Lidya, N.M., \& Rodiah. Hubungan pemberian ASI eksklusif dengan tumbuh kembang pada anak usia 
3 sampai 6 bulan di puskesmas karanganyar. 27 Desember 2012.

14. Anes MP \&Tri B.. Perkembangan Bayi yang diberikan ASI Eksklusif dan Tidak Eksklusif. FIK UI. Jakarta. 2013.

15. Anwar Mallongi, Herlianti, Hasnawati Amqam, Dwia Aries Tina Pulubuhu, Muhammad Arsyad, Muh. Saleh Jastam, Muhammad Rachmat, Calculation of Potential Risks Assessment of Escherichia coli and Total Coliform in Communities Well Water of Puty Village, Luwu Regency. Indian Journal of Public Health Research \& Development, July 2019, Vol. 10, No. 7

16. Rosmala Nur, Nikmah Utami Dewi, Khairunnisa and Anwar Mallongi, Golden standard feeding and the risk of 25-60 month-old underweight children in Central Sulawesi, Indonesia. Asian J. Clin. Nutr., 2017; 9: 104-110.
17. Chapman, L., \& Durham, M. Maternal newborn nursing: the critical components of Nursing Care. Philadelphia: F.A. Davis Company. 2010.

18. Santrock. J.W. Life-span development (Perkembangan Masa Hidup). Erlangga. Jakarta. 2002.

19. Bodnarchuk, \& Jennifer, L. The breastfeeding triangle: crawling as a mediator of breastfeeding duration and cognitive development at 2 years of age. UMI Dissertations Publishing. 2005

20. Wieslaw, J., Frederica, P., Jeffrey, J., Maria, B.,Elzbieta, M., Elzbieta, F., rena, K.,Ilona, L., Anita, S., Agata, S. Effect of Exclusive Breastfeeding on The Development of Children's Cognitive Function in The Krakow Prospective Birth Cohort Study. European Journal of Pediatrics. 2012; 8, 151. 